\title{
Reconstruction of Strengthening the Right to Sustainable Groundwater (Assessing Model Policy in Bandar Lampung City)
}

\author{
Erina Pane \\ Faculty of Sharia, Institut Agama Islam Negeri (IAIN) Raden Intan, Lampung \\ Jl. Letkol. H. Endro Suratmin, Sukarame, Bandar Lampung, Lampung 35131, Indonesia \\ Tel./Fax: +62-721-780887 E-mail: inapane@gmail.com
}

Submitted: Jun 21, 2016; Reviewed: Oct 3, 2016; Accepted: Oct 24, 2016

\begin{abstract}
Implementation of sustainable development related to the management of groundwater resources in the area can be realized with the establishment of a policy which is inseparable from the values prevailing in the society. The formation of ground water resources management policies is not only technically partial, but must also be comprehensive-holistic. Groundwater management activities include the conservation and utilization of groundwater organized to realize the sustainability and continuity of availability of groundwater and its sustainable benefit. Water resources policy in the form of government intervention should be able to improve the efficient use of water resources in an optimal and sustainable and should provide reinforcement right to water for the community. Weight of policy should be placed in a fair way, where the public interest, private interest and the government's interest is positioned in a balanced condition, but with the requirement that the parties are jointly responsible for creating actions in environmental improvements.
\end{abstract}

Keywords: Environmental Law; Natural Resources; Sustainable Groundwater; Sustainable Development

DOI: 10.20956/halrev.v2i3.701

\section{INTRODUCTION}

Natural resources are the elements forming the environment that are complex, dynamic, and interacting with each other. The controversy is the scarcity of natural resources that are limited, but the expansionary and exploitative economic activity is still tolerated because they bring benefits to humans. The exploitation of natural resources to support the development causes various problems, so as to arrange a new concept of develop- ment, i.e. sustainable development, which recommends that development carried out with due regard to environmental factors, where the construction will be done by taking into account the environmental carrying capacity (eco-development). ${ }^{1}$

\footnotetext{
Abdurrahman. (2003). "Pembangunan Berkelanjutan dalam Pengelolaan Sumber Daya Alam Indonesia". Paper presented on the Seminar and Workshop on Development of National Law VIII National Law Development Agency Ministry of Justice and Human Rights, Denpasar, Bali 14-18 July 2003, p. 1
} 
The concept of sustainable development was adopted in the concept of national development in the field of natural resources and the environment, where natural resource management should consider the fairness and is utilized for the welfare of the people by taking into account preservation of function and balance of the environment, sustainable development, economic interests and culture of local communities as well as spatial planning. Article 33 paragraph (3) of the 1945 Constitution stipulates that the process of natural resources in Indonesia surrounds the earth, water, and natural resources contained therein. The provision of this article provides affirmation of liberation and granting an obligation for the state to use the natural resources available for the greatest prosperity of the people.

Prosperity is also the rights of the present and future generations, so that prosperity to be achieved according to the Basic Law is trans-generation. Therefore, the right to prosperity must be continuous or sustain$a_{b l e}^{2}$, so that the process and use of natural resources need harmony and balance with environmental functions. This is in line with the development of environmental management, where the discourse of environmental regulation that can embrace the principles of fairness, sustainability and legal certainty arises.

\footnotetext{
Bagir Manan stressed that the definition of the statecontrolled understood generally include things outside of earth, air, and space, then the main element of state control is to "manage" (regelen en besturen). In order to understand the dominance of state said that the only bestuursdaad as manager (to manage) and did eigensdaad or actions as having. See, Bagir Manan. (2001). Menyongsong Fajar Otonomi Daerah. Yogyakarta: UII Press, p. 215
}

Environment is one system, in which related on water, forests, land and other environmental aspects. This paper took water resources to become the focus of discussion without ignoring the importance and the close relationship between water resources and the forest, soil and other ancillary aspects of the environment. Water is one of the components of nature and the environment that is the grace of God Almighty. Water is the material that makes life on earth happened. Goethe declared that "Everything originated is the water. Everything is sustained by water." The fact shows that as much as 70 percent of the earth's surface is covered by water, thus, without water, the whole movement of life is interrupted. Everyone needs water. Two-thirds of the human body consists of water. Everyone needs at least 50 liters of water for drinking, cooking, washing, sanitation, and to the growth of various types of plants every day.

Problems arose when it was realized that the water consumption continues to increase in line with population growth while the clean water sources has declined in terms of quality and quantity. Some people suffer from lack of water and lack of clean water, while in another part of the earth, men live homeless because of disasters caused by water. Human dependence on water will make the water as a source of conflict in the $21^{\text {st }}$ century, where currently around one billion people have no access to clean water, twice the amount do not have adequate sanitation and every year three million people die from various diseases caused by water, while the water supply is always reduced by various causes. Meanwhile, water consumption in 
the world has doubled in every 20 years. If it continues like this then in 2025 more or less five billion people (approximately 65 per cent of the world population) suffers because they do not have access to drinking water. Water is an integral part of human rights itself. This right is implicitly articulated in The International Covenant on Economic, Social and Cultural Rights. ${ }^{3}$ Viewed from any perspective, the water can never be separated from life; even water is life itself (aqua vitae, life water).

Water is needed in every aspect of life. In general, the quality must be maintained, where it is to be implemented in the policy of area development. The most important thing in any development policy on the management of water in the area is that the water is associated with social, economic, and environmental. Therefore, this article relates to the management of groundwater resources starting from the government's policy on water, water supply, and protection of ecosystem functions. It is assessed by assuming that these policies relate to the fundamental right to take advantage of clean water. Each region should have the same perspective on the sustainability of life, as well as the city of Bandar Lampung. Bandar Lampung city has a land area of 197.22 square kilometers with a population of 1.446 .160 inhabitants with a population density of about 8.546 inhabitants/square kilometers, and a popula-

\footnotetext{
Articles 11 and 12, including General Comment No.15 (2002) adopted by the United Nations Committee on Economic, Social, and Cultural Rights, entitled "The right to water". It is affirmed in Article 11 concerning the right or decent living standards on the one hand and the state's obligation to comply on the other side. Whereas in Article 12 on the right to spiritual and physical health, which is one of the most important elements in it is a matter of environmental health is closely linked to water.
}

tion growth is expected to reach 2.4 million in 2030. With that population growth, there should be a consideration on how Bandar Lampung City residents meet the need for clean water. Policies become one of the instruments in water resources management. Characteristics of water resources in the form of public goods require government intervention to regulate and steer. Policy in the management of water resources is a form of government intervention in the management of water resources, where policies related to other policies, and the success of a policy should be supported by the system.

Water resources policy in the form of government intervention should be able to improve the efficient use of water resources optimally. Weight of policy should be placed in a fair way where the public interest, private interest and the government's interest is positioned in a balanced condition, but with the requirement that the parties are jointly responsible for creating actions in the improvement of environments. To that end, the policy will not run effectively under weak law enforcement conditions. Law enforcement will force every member of the public to comply with the policy set.

\section{METHOD}

This study uses normative juridical approach. The primary research material in this study is the policy and Regional Regulation of Bandar Lampung related to water resources. Legal materials in this study were classified into 3 (three) categories, namely (1) the primary legal materials (primary law material) in the form of binding legal materials in general such as legislation related to 
water resources management. (2) secondary law material obtained from the reference legal and non-legal form of research results, the legal literature that support the issue. (3) tertiary legal materials (tertiary law material) is a material obtained through the use of law dictionaries, encyclopedias providing an explanation for primary legal materials and secondary law. Material of non-law as a complementary of secondary data obtained by conducting field research, where data obtained by conducting interviews with competent parties, namely the agencies concerned with environmental protection and water resource management.

Data processing begins with the data inspection process (editing), the data tagging process (coding), and the data systematization process (constructing/systematizing). After da-ta processing, data analysis process is begun by describing data with qualitative juridical methods. In the end, the conclusion is drawn by using an inductive method where the generalization as the conclusion in this study is drawn from data analysis specifically based on the object under study. ${ }^{4}$

\section{ANALYSIS AND DISCUSSION}

\section{Principles of Sustainable Environmental}

\section{Management}

General principles in the management of the environment are a reflection of various actions of the international community. As outlined by Philippe Sands, that:

"... the general principles and rules of international environmental law as reflected in treaties, binding acts of inter-

\footnotetext{
Jonny Ibrahim. (2005). Teori \& Metodologi Penelitian Hukum Normatif. Malang: Bayumedia Publishing, p.
} 42 national organization, state practice and soft law commitments. Some general principles or role may reflect customary law, others may reflect emerging legal obligations, and yet other might have an even less developed legal status." 5

The whole of these principles is intended for global protection and control activities of the state in the jurisdiction that does not affect the environment of other countries or territories outside the national jurisdiction. ${ }^{6}$ As general principles resulted from the Conference in Stockholm in 1972 and in Rio de Janeiro Conference in 1992 arise from the reflection of the turmoil of the international community on environmental quality degeneration, so a strategy of international development must be established in order to save the ecological balance and harmony for the sake of human survival.

The complete general principles are on (1) the obligation contained in Principle 21 of the Stockholm Declaration and Principle 2 of the Rio Declaration concerning state sovereignty over natural resources and the responsibility of not causing harm the environment for other countries or areas beyond national jurisdiction, (2) the principle of preventive action, (3) the principle of good neighborliness and international cooperation, (4) the principle sustainable development, (5) the precautionary principle, (6) the polluter-pay principle and (6) the principle of common but differentiated responsibility. ${ }^{7}$

\footnotetext{
Philippe Sands. (1995). Principle of International Environmental Law 1, Frameworks, Standards and Implementation. UK: Manchester University Press, p. 183

6 Patricia W. Birnie and Alan E. Boyle. (1992). International and the Environment. Oxford: Oxford University Press, p. 9

Philippe Sands, Op. Cit., p. 183
} 
Sustainable development is an approach that is based on the consideration of linkages and interdependence of economic development, social development, and environment. The conception of sustainable development comes from economics which is mainly associated with the issue of efficiency and fairness (equity) to promote sustainable economic development for the welfare of society. Definition of terms of the economy is also motivated by the biological sciences that address sustainability in terms of capability and suitability of a location with regenerative potential/productivity of the environment.

Since the 1980s the political agenda of the environment began to be concentrated on the paradigm of sustainable development. Mentioned in the report of the Brundtland Commission in 1987 and in the report of the World Commission on Environmental and Development (WCED) $)^{8}$ "Our Common Future" formulated that sustainable development as development that meet the needs of the present without comprising the ability of future generations to meet Reviews their own needs. ${ }^{9}$ In this case sustainable development is defined as development that meets the needs of the present without compromising the ability of future generations to meet their own needs.

Development that meets the needs of the present without compromising the ability of future generations to meet their own needs, contains two concepts, ${ }^{10}$ namely: The

\footnotetext{
8 World Comission on Environmental and Development (WECD) was formed by The United Nations in compliance with a decree of the UN General Assembly December 1983 No.38/161

9 Abdurrahman, Op.Cit., page 1

10 Philippe Sands, Op. Cit., p. 201
}

concept of "needs", in particular the basic needs of the present generation; and the thought of the idea of "limitation" that is based on the consideration of technological progress and social organizations to establish the environmental carrying capacity that can sustain the life of the current generation and the future.

The statement was a compromise between the concept of needs and limitations, where the fulfillment of human needs is the purpose of development that must be aligned with the reality that natural resources are limited, and therefore the balance between development and the environment should still be considered in all decision-making at the national level. ${ }^{11}$ On the other hand, there is inter- and intra-generation equity in the use of natural resources to meet their needs. In other words, the core of sustainable development is fairness and sustainability ${ }^{12}$ where the sustainable approach can be based on the determination of standards maintenance in the use or exploitation of natural resources in particular for future generations ${ }^{13}$, by considering the needs and capabilities of different countries and the contribution of the countries on specific issues.

Furthermore, based on the Report of Brundtland Commission, ${ }^{14}$ some critical issues that need to be used as the basis of environmental policy for the concept of sustainable development have been identified,

\footnotetext{
11 Otto Soemarwoto. (2005). Menyinergikan Pembangunan \& Lingkungan, Telaah Kritis Begawan Lingkungan. Yogyakarta: Anindya, p. 34

12 Rachmadi Usman. (2003). Pembaharuan Hukum Lingkungan Nasional. Bandung: Citra Aditya Bakti, p. 68

13 Philippe Sands, Lpc.Cit.

14 Daud Silalahi. (1996). Hukum Lingkungan Dalam Sistem Penegakan Hukum Lingkungan di Indonesia. Bandung: Alumni, p. 12
} 
among others, is Reviving growth and changing its quality, meeting essential needs for jobs, food, energy, water, and sanitation, ensuring a sustainable level of population, conserving and enhancing the resource base, reorienting technology and managing risks and integrating environmental considerations into economic decision-making process (emerging environment and economics in decision-making).

The concept of national development in the field of natural resources and the environment today has adopted the concept of sustainable development. Where the management of natural resources should consider the fairness and utilized for the welfare of the people by taking into account preservation of function and balance of the environment, sustainable development, and economic and cultural interests of the local community as well as the arrangement of space. Those principles can provide a formal foundation in the sustainable management of natural resources, so as to set the policy direction in the management of natural resources.

Policies directed to (1) reexamining the legislation relating to the management of natural resources in the socialization of policies across sectors, (2) optimizing the use of various natural resources through the identification and inventory of quality of natural resources as a potential development, (3) expand provision access to information to the public about the potential of natural resources in the region and promote social responsibility to use environmentally friendly technologies, including traditional technologies, (4) pay attention to the nature and characteristics of the various types of natural re- sources and make efforts to increase the value added of the products of those resources, (5) resolve conflicts of utilization of natural resources that arise during this time as well as to anticipate potential conflicts in the future in order to ensure the implementation of law enforcement based on the principles of management sustainable natural resources, (6) seeking restoration of ecosystems that have been damaged as a result of excessive exploitation of natural resources, (7) develop strategies on the use of natural resources that is based on the optimization of benefits with regard to the potential, contributions, interests of society and the national and regional conditions.

The existence of the principles of sustainable development has implications for the formation of national law in natural resource management. Sustainable principle is used as a standard level of utilization or exploitation of certain natural resources where sustainable is interpreted as optimal utilization based on standards that ensure the preservation of the environment. This has resulted in new demands on the national legal systems of natural resources. The formation of the legal system of natural resources with the new concept has many benefits that can be felt as the legal establishment in the area, where David Silalahi ${ }^{15}$ argues that there are some things that will affect the legal establishment in development in the area, that strengthening of the position of the area on natural resource management in which institutions and institutional capacity in the area can run effectively, and the establishment of local regulations in sustainable development

$15 \quad$ Ibid., p. 19 
in the management of natural resources oriented to the role of stakeholders in the area will take effect on other forms of public participation to develop forms of public consultation.

\section{Sustainable Development in Water Re- sources Management}

The fundamental challenge for the management of water resources is how to facilitate the development, both in the economic field and in other fields and at the same time minimizing the negative impacts of all development activities and natural disasters suitable with the capacity of the supportive environment, but according to the changing times, today the meaning of life is changing. The meaning of life is used to obtain the figures, so that the roots of life are in the economic and physical parameters.

The question that arises is how the real meaning of human life is in which human life is never undermined by the existence of the universe in which man lived his life. Rousseau, ${ }^{16}$ expressed as a protest against civilization that considers human distanced from its essence and of his fellow man. Artificial ways imposed by the civilization of mankind is a source of individual and social alienation of the natural environment.

The presence of water for humans to support life and livelihood is something that is absolutely necessary. Concerns occur when there is an imbalance between the availability which increasingly does not match the needs. In another point of view, insecurity also occurs from the point of qual-

\footnotetext{
16 Henryk Skolimowski. (2004). Filsafat Lingkungan, Merancang Taktik Baru untuk Menjalani Kehidupan. Yogyakarta: Bentang, p. 12
}

ity, temporal and spatial of the water source itself.

Since the 1980s, oil and gas resources are no longer a priority, but it does not mean that Indonesia has been free from dependence on natural resources. The controversy is the scarcity of natural resources is limited, but the expansionary and exploitative economic activities are still being tolerated for the human benefit. At that time, the construction carried out focused on technology aimed at spurring economic growth. Economic growth that has not reached the goal has damaged joints sustainability of natural resources, including water resources. The perceived negative impact on the Indonesian people is quite extensive.

Mismatch management of upstream and downstream conditions have caused setbacks of Watershed, causing erosion and sedimentation, floods and droughts and increasing competition for water acquisition between users. Setbacks condition is also caused by excessive exploitation of groundwater, causing a decline in ground water frying, raising the sea water intrusion and land subsidence. Moreover, the mismatch use of inorganic fertilizers and industrial pollution also causes an increase in pollutants dissolved in water up pass the allowable threshold.

Persistent mismatch will cause an unsustainable situation. To be able to do a reform policy that wants continuity, it is necessary to an understanding of the concept of sustainability. The concept of sustainable development is a cornerstone in the management of water resources. The fundamental challenge for the management of water re- 
sources is how to facilitate economic development and at the same time to minimize the negative impacts of all development activities and reduce the risk of natural disasters according to the carrying capacity of the environment.

\section{Water for Human Needs}

Water is an integral part of human rights itself. This right is implicitly articulated in the International Covenant on Economic, Social, and Cultural Rights, particularly Article 11 on the right to adequate standard of living as the state's obligation to comply on the other side. In Article 12 on the right to spiritual and physical health, one of the most important elements in it is a matter of environmental health which connects closely with water. It is explicitly referred in the General Comment on the convention.

Human rights in the disciplines of human rights are given the position as "Guaranteed constitutional right". The Rights become constitutional rights, therefore, rights are not "regulated rights", whose fulfillment depends on legislation or government regulation alone. The Human rights contains universal values, should not be deregulated, limited, or omitted in part or in whole, including through enactment of an applicable law in a country.

More specifically, regarding the right of water where on April 27, 1999, The United Nations Commission on Human Rights has adopted Decision 1999/108 which states that "the right to drinking water and sanitation is a human right". Likewise, Resolution of Sub-Commission on Prevention of Discrimination and Protection of Minorities
1998/7 which states that "the right to water and sanitation for all men, women, and children is a fundamental principle of equality, human dignity, and social justice".

Furthermore, Resolution No. 2000/8 adopted by the Sub-Commission on Human Rights states that "promotion of the realization of the right to drinking water and sanitation." There is a sub-commission form of concern to more than one million people worldwide who suffer from lack of access to drinking water and more than four million people worldwide living in inadequate sanitary conditions. In this resolution, Article 2 is declared:

"... the effect that various obstacles linked to the realization of the right of everyone to drinking water supply and sanitation seriously impede the realization of economic, social and cultural rights, and that equality is an essential element for effective participation in the realization of the right to development and the right to a healthy environment."

The statements of this kind are repeated, as stated in the Commission on Human Rights Resolution 2003/71, "Human Rights and the environment as part of sustainable development'. The right to water as a human right contained in the various international standards and norms on human rights, such as: International Covenant on Economic, Social, and Cultural Rights, Article 11 and 12, including General Comment No. 15 of 2002 which is adopted by the United Nations Committee on Economic, Social, and Cultural Rights, entitled "the right to water". Sergio Vieira de Mello, the United Nations High Commissioner for Human Rights has stated the right to water is an integral component of 
the human right to adequate standard of living, and also the right to live as published in the United Nations Press Release.

The importance of the right to water as a human right contained in various standards and norms of international law, such as the resolution of the United Nations adopted in the United Nations Water Conference, held in Mar del Plata, Argentina on April 14 to March 25, 1977, General Assembly resolution 35/18 of the United Nations on 10 November 1980 and 47/193 dated December 22, 1992 of the International Drinking Water Supply and Sanitation Decade (1981-1990) and the statement of the Celebration of World Water which falls on March 22 each year.

In the Preamble of the Universal Declaration of Human Rights paragraph 5 it states: "Considering that the peoples of the United Nations once again have declared in the United Nations Charter their belief in the basic rights of the dignity and value of a person and would equal rights of men and women and have determined to promote social progress and better standards of life in larger freedom.

The above statement considers that the right to water is a fundamental and universally applicable, so that states and governments have an obligation to protect, to respect, and to fulfill this right. This is in accordance with the International Covenant on Economic, Social, and Cultural Rights as one instrument of International Customary Law (in addition to the Declaration of Human Rights and the Covenant on Civil and Political Rights), so that even though Indonesia has not ratified it, but the instrument binds universally. It is also in accordance with the Preamble of the
1945 Constitution, which declared that:

"... and then to form a Government of the State of Indonesia that protects all Indonesian people and the entire land of Indonesia and to develop the welfare of the people, the life of the nation, and participate in the world orderliness based on freedom, eternal peace and social justice..."

Viewed from any perspective, the water can never be separated from life; even water is life itself (aqua vitae, water of life). In the perspective of the concept of human rights, in terms of relationship between the state and its citizens, the people's position as the holder of rights (right holder), while on the other side, the country serves as the carrier of liability (duty holders). The state's fundamental obligation is to protect and guarantee the rights of its citizens (the people) of which one was right on the water, seek fulfillment in a positive or guarantee people's access to healthy water for all their needs ranging from housekeeping, irrigation, and affairs of other production.

The world's attention to the use of water is so great. There seems to be a consensus that there is a right to the so-called rights to water, then known as the discourse of human rights. In this case, each state is required to perform its functions to ensure (provider) in the implementation of human rights. If it is about the right to water, the state is obliged to carry out a fair share to any interested party on the water. On the other hand, it is known that many parties interested in the water, including the country even in this case serve as a principal of economic business (entrepreneur). A state, in the management of water resources, acts and protects the ex- 
ercise of a number of regulations. This is done to protect the rights of every individual and community of water user. This effort is made to provide equal protection before the law, with its interpretation to reject discriminatory procedures in terms of acquiring the rights to water. Furthermore, concerning the right of ownership over the water, the state can limit interference in the rights of ownership by powerful economic interests. Thus, the state acts positively through regulation, coercion in limiting the power to intervene, or to interfere with the rights of individuals either by the government itself or by other institutions or individuals.

\section{Groundwater Resources Management Policy in Bandar Lampung City}

Based on BPS census (in 2012), the city of Bandar Lampung has a population of 1.446.160 inhabitants, with an area of approximately $197.22 \mathrm{~km}^{2}$, then the population density is 8.546 people $/ \mathrm{km}^{2}$ and a population growth rate is $1.79 \%$ per year with the state of humid throughout the year, where rainfall ranges between 2257-2454 $\mathrm{mm} /$ year. The numbers of rainy days are 76-166 days/year. Air humidity ranges from $60-85 \%$, and the air temperature is $23-37{ }^{\circ} \mathrm{C}$. Bandar Lampung city has two major rivers namely Way Kuripan and Kuala Way, and 23 small rivers. All these rivers are watershed located in the area of Bandar Lampung city and largely empties into the Gulf of Lampung. With groundwater aquifer productive, there are only several districts. ${ }^{17}$

17 Kedaton, Tanjung Senang, the southern part of the SubDistrict Kemiling, southern part of West Tanjung Karang, and a small portion Sub-District of Sukabumi
Based on the data above, it can be analyzed the public demand for clean water, but has not been fulfilled by existing groundwater sources. Therefore, the management should be able to guarantee the fulfillment of the affluent in a sustainable manner. Groundwater beneath the surface of the soil on land and under the sea follows the distribution of the characteristics of a presence that is in the soil or rock layers on the groundwater basin. The government Policy Bandar Lampung city in managing groundwater is based on:

\section{Management principles}

Soil water availability is in the soil layer in the form of ground water basin. Groundwater basin covers areas where the incident took place hydro geological. Based on the coverage breadth, the groundwater basin is not always the same as administrative boundaries, even on the territory of groundwater basins can encompass more than one area of the city administration, then the management of groundwater in the basin should be integrated which includes regional augmentation, streaming, and capture. Therefore, regulation is done by the provincial government together with city authorities in order to realize comprehensive and integrated policy in the region ground water basin.

\section{Event planning}

The planning utilization aims to carry out the planning of the groundwater, land use in the catchment areas, drainage areas, and regions retrieval. Surveillance and control aim to supervise and control the activities and the extraction of ground, both from the technical aspects and the quality and quantity. 


\section{Event management}

In principle, ground water management activities are divided into the inventory, conservation, and utilization of ground water. Inventory is intended to determine the condition of ground water potential in each groundwater basin as well as to determine the condition of ground water throughout the basin. Conservation aims to make the protection of groundwater hydrology entire structure and activities of monitoring ground water level as well as the recovery of the basin that has been declared hostile or critical.

\section{Licensing}

Licensing of groundwater is one means of controlling the management of ground water. Granting permissions of groundwater abstraction are issued by the Mayor. In order that execution of management takes place in an integrated manner in a groundwater basin that covers more than one area of the city, it is necessary to set the same policy. In terms of water withdrawal, the permits are granted by the mayor after considering the requirements / technical recommendations from the provincial government. In accordance with its function, the permit of the extraction of ground is the basis for the establishment of groundwater tax.

\section{Implementation activities}

The implementation of groundwater is done in a coordinated way between the provincial and city governments. Insofar as it concerns matters of a technical nature and provincial governments provide support facilities, as the basis for the implementation of administrative management by the City.
The policy of Bandar Lampung city government in groundwater management is aimed at achieving a balance between conservation and utilization of ground water. Therefore, structured planning of bending can be changed according to changes in the future. A hydrological condition in the future is uncertain, and economic, social and legal laws will continue to change. Such plans include constraints in the economic, social, institutional, and legal. Therefore, the implementation of groundwater management plan covers the relationships between the fields concerned.

In conducting groundwater management plan, there are things to be considered (1) the economic aspect. This consideration of the alternative plan appears by comparison of cost differences, advantages, and settlement, so the best plan was chosen. There is overall estimation of the total cost from the total profit earned. It is social and institutional considerations. In choosing a management plan, the plan that is most economical is considered, and it also considers (2) aspects of the social structure of groundwater by establishing an advisory board in the social sphere that represents the aspirations of the users of groundwater, so as to minimize social conflict in the planning stages of groundwater. (3) The legal consideration is made before, during, and after the investigation of groundwater management. The right to groundwater is set in the allocation of operating costs.

\section{Inventory of groundwater}

Inventory of groundwater is conducted to obtain data and information on groundwa- 
ter as a basis for planning the management of ground water, to determine the condition of hydrology, hydrometeorology, hydrogeology, potential availability of water resource, and water requirements related to both quantity and quality, along with the infrastructure and facilities and environment, including the conditions socio-economic and cultural community. The authority regarding the inventory in Bandar Lampung city is the hands of the mayor, and in the implementation, they commission a college in the city of Bandar Lampung, and business entities that have competence in the field of groundwater.

\section{Determination of ground water conserva- tion zone}

Determination of soil water conservation zones is carried out to determine the rate of change in environmental conditions and ground water caused by natural processes or by human activity. The implementation of the determination of conservation zones is done to determine soil water conservation efforts in the activities of utilization of ground water. Determination of soil water conservation zones is one of the elements to plan-making, supply, utilization, development, exploitation of ground water, and spatial plans in a groundwater basin

Zone of soil water conservation is determined by factors of availability and potential of soil water availability, changes in groundwater levels, changes in groundwater quality, environmental changes of groundwater, availability of water sources other than groundwater, priority use of groundwater and the interests of society and development. Based on these factors groundwater conservation zone of an area is divided into categories of secure, vulnerable, critical, and degraded, which is then presented in map form. The draft plan of management of ground water in the city of Bandar Lampung consists of long-term, medium-term, and the short term with the details as follows:

a) A long-term plan of groundwater management program includes the main points of conservation and utilization of ground water for a period of 20 years.

b) Medium-term plan of groundwater management program includes the main points of conservation and utilization of ground water for a period of 5 years.

c) Short-term plans of groundwater management activities include the main topics of conservation and utilization of ground water for a period of 1 year.

The draft of groundwater management plan is announced openly to the public by the Mayor of Bandar Lampung in accordance with its authority. A public announcement can be made via notice boards, print media, and / or electronic media. The public can submit objections to the draft of groundwater management plans that have been announced within a maximum period of 30 calendar days from the date announced. The draft of groundwater management plan is then determined by the Mayor of Bandar Lampung in accordance with its authority into ground water management plan in the city of Bandar Lampung.

In principle, the management of groundwater resources include conservation, utilization, and control of water dam- 
age. Maximum use of natural resources and still direct the sustainability of resource use can be interpreted as an act of conservation. Groundwater management is carried out in accordance with ecosystems in nature. Groundwater management is not based on the administrative area, but in one unified whole water balance according to the ecosystems, ranging from the recharge area to local detachment (discharge area) in a container called groundwater basin. This policy aims for all groundwater management activities include conservation, utilization, control, and supervision to be implemented in one groundwater basin which includes regional augmentation to its detachment according to ecosystems. Moreover, the distribution and the potential for groundwater that is uneven in nature require that each decision and its utilization should consider the ability of the aquifer to its potential in nature so that the ability of supply is sustainable.

Priority use of water for drinking is given in the form of protection for the public to obtain the right to water. Some policies to control land use for ground water, among others setting technical requirements in granting drilling permits, the absorption spring, and decision-making as well as restrictions on discharge. This policy aims to protect the environment of groundwater resources as well as maintain the continued existence of ground water to be able to sustain the needs of ground water for longterm period and for the future. Especially in the use of ground water for industry it gradually needs to be reduced and replaced by a surface of water supply. This policy was urged to meet the water needs of the industry in every city that has industrial centers. Determination of industrial area, especially the type of industry that requires a lot of water as raw materials and management needs to consider the carrying capacity of the availability of water resources, particularly surface water, and avoid dependence to use ground water.

In order to monitor the possibility of environmental damage of ground water there are policies that govern that drilling permit of groundwater to the fifth wells or the multiplicity on an area less than 10 ha or the amount of ground water is equal to or greater than 50 liters/sec of one or more wells in one area less than 10 ha. It is required to build one (1) monitoring wells completed with hardware of Automatic Water Level Record$e r$. In addition, it is required also for users of groundwater to include documents of efforts to manage the environment and environment monitoring for groundwater equal to or greater than 50 liters/details of one or more wells in an area of less than 10 ha. It is required to include the document of EIA (Environmental Impact Analysis).

Supervision in the field of groundwater is under the authority of provincial and district/city government, where the primary focus is on the unlicensed artesian well and the licensed artesian well that is proven to damage the environment. In the efforts to curb the artesian well without permission, the provincial government and district/city are in a dilemma between doing the controlling (closing) of the wells or to let go with a big flat tax. Law enforcement against unauthorized wells that proved to have caused environmental damage of groundwater needs to 
be done immediately. Potential damage by drilling wells without permits is much greater because it does not include the technical requirements and supervision when building the well construction. District/city governments have a responsibility for the preservation of the environment in the region, including environmental land resources.

Ground water management policies in Bandar Lampung city are taken by expediency for some parties. As the theory of utilitarianism explains that the important thing underlying any decision or policy is how the consequences or effects of the action or the policy are. Water resource management policy is indeed associated with benefits for local governments, stakeholders and the public at the scene of the water resources. The question then is of some of these parties, whether the public has got prosperity, because in accordance with the mandate of the constitution that the management of natural resources including water resources is for the welfare of the people. People are referred to here are the people who are in the vicinity of the existence of these natural resources including indigenous communities.

Furthermore, are local governments that seek water resources are not expecting the same thing because in the period of regional autonomy, each region is vying to be able to increase revenue that can be generated from natural resources in the region, including water resources? When combined with the theory of utilitarianism, it is necessary to supervise the management of water resources without having to question who do the management. A decision taken is not for the interests of local governments only, but also for preserving the rights of the people in the area. Although the investor can support regional development, but they still have to pay attention to the sustainability of local life in the future as the principle of sustainable development.

One problem that exists in the observation is that the distribution of water between users within the above needs to consider the elements of justice. It means that water users should get the parts as needed, where the use of water among users is expected to provide optimal benefit which holds the principle of value to the limit (marginal value in use) between the holders must always be the same. In terms of distribution, problems may arise where the amount of water to be distributed is limited, so that there are necessary efforts to maintain water capacity available in a certain period. It can be affirmed that in the utilization and management of water resources should pay attention to fairness.

In the context of the economy, there must be justice for the water users. It can be translated that every individual is entitled to seek water resources. If there are water resources in the area, then the rights to use and manage water resources go to local communities, local governments, and entrepreneurs in the area. In this case the public deserves to have water for their needs, local governments are also entitled to the results of water resource management, and employers are also entitled to the opportunity to manage water resources in its capacity as employer.

John Stuart Mill ${ }^{18}$ links justice, usability, individual interests, and the public

\footnotetext{
18 John Stuart Mill as cited on W. Friedmann. (1990). Teori dan Filsafat Hukum. Telaah Kritis atas teori-Teori Hukum. Jakarta: Rajawali Pers, p. 120.
} 
interest. Mill emphasizes on the existence and nature of justice to do with usability. It was understood correctly that traditionally, timeless idea of justice and injustice is on the contrary to the ideas that change and less valuable on the usefulness and importance. There are changes in pressure that is above individual interests to the pressure of public interest, and the reality is that the obligation is better than the rights.

One synthesis of Mill on the relationship between justice and the usefulness of that relationship is a sense of justice. In essence it means that the individual feeling of justice makes people regret and wants to take revenge on each something unpleasant. The morals are mitigated and corrected by social feeling. Mill explained that good people deplore no good deeds to society, even if not of themselves, and did not regret the act that is not good for themselves even though it is painless, except when people intend to do an oppression. ${ }^{19}$

There is always a conflict in discussion about justice between the individual benefit and the general benefit. Measures taken in implementation of the management of water resources should be looked far ahead, not only for practical purposes. Law as a servant to the social goals should protect the social interests. Based on the above it can be concluded that any development in areas that take advantage of natural resources has always had a dual objective, among others, the development aimed at improving the local economy and their efforts to maintain environmental functions. The fundamental challenge for the management of water resources

19 Ibid. is how to facilitate development, both in the field of economic development as well as in other fields and at the same time minimizing the negative impacts of all the development activity and natural disasters appropriate with carrying capacity.

Water is a natural resource that is very strategic. The more increase of demand for water resources, the more increase of extractive water resources management. In keeping with the availability of water resources in the area, the use of water resources is continued to be directed to sustainability of maximum use of the water resources in an action development and protection of natural resources. Water resources today have become economic goods, so that the various parties seek to utilize the maximum in the implementation of economic functions and in an effort to increase the value of the benefit of water resources.

\section{CONCLUSION}

The ground water has an important role to the lives and livelihoods of the people in the city of Bandar Lampung, given its function as one of the basic necessities of life. Groundwater is managed wisely, comprehensively, integrally, sustainably, and sounds environmentally. Groundwater management is technically need to be tailored to the behavior of groundwater include availability, deployment, and quality of groundwater and the surrounding environment thereof. Ground water management policies in Bandar Lampung were established by the Mayor in accordance with the authority. Groundwater management in Bandar Lampung city is directed on the balance between conserva- 
tion and utilization of ground water that is integrated into policy and patterns of water resource management. The main activity in the management of groundwater in the city of Bandar Lampung includes the conservation and utilization of ground water held to realize the preservation and sustainability of soil water availability and usefulness of groundwater sustainably. The groundwater management aims to achieve sustainability, continuity, availability and usefulness of ground water that is sustainable for the prosperity of the people and the implementation of conservation, utilization, empowering and increasing the role of officials and the community and to improve the provision of data and information.

\section{BIBLIOGRAPHY}

Abdurrahman. (2003). "Pembangunan Berke-lanjutan dalam Pengelolaan Sumber Daya Alam Indonesia". Paper presented on the Seminar and Workshop on Development of National Law VIII National Law Development Agency Ministry of Justice and Human Rights, Denpasar, Bali 14-18 July 2003.

Bagir Manan. (2001). Menyongsong Fajar Otonomi Daerah. Yogyakarta: UII Press.
Daud Silalahi. (1996). Hukum Lingkungan Dalam Sistem Penegakan Hukum Lingkungan di Indonesia. Bandung: Alumni.

Henryk Skolimowski. (2004). Filsafat Lingkungan, Merancang Taktik Baru untuk Menjalani Kehidupan. Yogyakarta: Bentang.

Jonny Ibrahim. (2005). Teori \& Metodologi Penelitian Hukum Normatif. Malang: Bayumedia Publishing.

Otto Soemarwoto. (2005). Menyinergikan Pembangunan \& Lingkungan, Telaah Kritis Begawan Lingkungan. Yogyakarta: Anindya.

Patricia W. Birnie and Alan E. Boyle. (1992). International and the Environment. Oxford: Oxford University Press.

Philippe Sands. (1995). Principle of International Environmental Law 1, Frameworks, Standards and Implementation. UK: Manchester University Press.

Rachmadi Usman. (2003). Pembaharuan Hukum Lingkungan Nasional. Bandung: Citra Aditya Bakti.

W. Friedmann. (1990). Teori dan Filsafat Hukum. Telaah Kritis atas Teori-teori Hukum (Susunan I). Jakarta: Rajawali Pers. 